Int. J. Dev. Biol. 56: 273-278

doi: $10.1387 / \mathrm{ijdb} .113378 \mathrm{ks}$

\title{
Retinoic acid stability in stem cell cultures
}

\author{
KYLE A. SHAROW, BORIS TEMKIN and MARY ANN ASSON-BATRES* \\ Department of Biological Sciences, Tennessee State University, Nashville, TN, USA
}

\begin{abstract}
It has been reported that retinoids, such as retinoic acid (RA) and retinol (ROL), dissolved in aqueous solutions are susceptible to oxidative damage when exposed to light, air, and relatively high temperatures, conditions that are normal for culturing stem cells. Thus, questions arise regarding the interpretation of results obtained from studies of mouse embryonic stem cells exposed to retinoids because their isomerization state, their stability in culture conditions, and their interactions with other potential differentiation factors in growth media could influence developmental processes under study. Media samples were supplemented with retinoids and exposed to cell culture conditions with and without mouse embryonic stem cells (mESC), and retinoids were extracted and analyzed using HPLC. To determine whether retinoids are stable in media supplemented with fetal bovine serum (FBS) or in chemically-defined, serum-free media, mESC adapted to each type of growth media were investigated. Studies reported here indicate there was little loss or isomerization of at-RA, 9-cis-RA, 13-cis-RA, or ROL in cell cultures grown in serum-supplemented media when cell cultures were maintained in the dark and manipulated and observed under yellow light. In contrast, the stability of both at-RA and ROL were determined to be greatly reduced in serum-free media as compared with serum-supplemented media. Addition of $6 \mathrm{mg} / \mathrm{ml}$ bovine serum albumin was found to stabilize retinoids in serum-free media. It was also determined that ROL is less stable than RA in cell culture conditions.
\end{abstract}

KEY WORDS: retinoic acid, cell culture condition, retinoid integrity

\section{Introduction}

Retinoic acid (RA) has been shown to influence cell proliferation, differentiation, maturation, and apoptosis (Duong and Rochette-Egly 2011; Gudas and Wagner, 2011; Caricasole et al., 2000; Baharvand et al., 2007; Crnek et al., 1991). To decipher mechanisms underlying these effects, in vitro studies have been carried out using cells cultured in growth media supplemented with RA (Gubler and Sherman 1985; Williams and Napoli 1985; Gudas and Wagner 2011; Strickland and Mahdavi 1978; Zouboulis et al., 1999; Redfern and Todd 1988). In these and many other published studies (too numerous to be cited here), a variety of protocols have been followed and a broad range of RA concentrations (nanomolar to micromolar) have been used to investigate RA effects on cell processes. In some protocols, RA has been provided in growth media supplemented with serum and in others, in serum-free media.

Retinoids dissolved in aqueous solutions are susceptible to oxidative damage when exposed to light, air, and high temperature in the absence of protein or antioxidants such as vitamin $C$ and $E$ (Szuts and Harosi 1991; Klaassen etal., 1999). Additionally, retinoids are adsorbed by glassware and plasticware (Klaassen et al., 1999;
Noy 1992). These cautionary dictums raise important questions regarding the stability and integrity of retinoids in cell cultures. Early studies analyzing the metabolism and turnover of RA and ROL in cell cultures provided qualitative evidence that retinoids survive cell culture conditions intact in medium supplemented with fetal bovine serum (FBS) (Williams and Napoli 1985; Gubler and Sherman 1985), but a specific quantitative study analyzing the status of retinoids in serum-deprived and serum-supplemented media under cell culture conditions has not been previously reported.

This study was designed to determine whether retinoids are stable in growth media maintained under cell culture conditions. The results indicate that with careful handling, $R A$ and $R O L$ retain their integrity in cultures when serum or bovine serum albumin (BSA) is present in growth media. In contrast, even with careful handling, at-RA isomerizes and ROL is lost when added to serum-free media and maintained under cell culture conditions (without cells) for $24 \mathrm{~h}$.

\footnotetext{
Abbreviations used in this paper: BSA, bovine serum albumin; DMEM, Dulbecco's minimal essential media; FBS, fetal bovine serum; mESC, mouse embyronic stem cell; RA, retinoic acid; ROL, retinol.
}

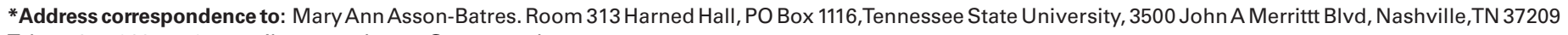
Tel: +1-615-963-5779. e-mail: massonbatres@tnstate.edu
}

Accepted: 13 September 2011. Final, author-corrected PDF published online: 28 March 2012.

ISSN: Online 1696-3547, Print 0214-6282 


\section{Experimental Protocols}

\section{Chemicals}

Retinoids were purchased from Sigma-Aldrich, St. Louis MO. HPLC-grade reagents were obtained from Fisher Scientific Inc. (Pittsburgh, PA).

\section{Media and cells}

R1 mouse embryonic stem cells (R1 mESCs, from William Stanford, University of Toronto, Canada) were adapted to growth in serum-supplemented growth media. Cells were maintained in high glucose Dulbecco's Minimal Essential Media (DMEM) with GlutaMax $^{\text {TM }}$ (Invitrogen, Carslbad, CA) supplemented with 15\% FBS (Atlanta Biological, Lawrenceville, GA) and $50 \mathrm{U} / \mathrm{ml}$ Penicillin/50 $\mu \mathrm{g} / \mathrm{ml}$ Streptomycin. C57/BL6 mESCs (BL6 mESCs,) were adapted to growth in chemically defined, serum-free media and were maintained in ESGRO Complete Plus Medium (Millipore Corporation, Billerica, MA).

\section{Retinoid supplementation studies}

All operations were carried out under yellow light because retinoids do not absorb light in the yellow range of the electromagnetic spectrum (570-585nm). Concentrated stock solutions of at-RA, 9-cis-RA, 13-cis-RA, and ROL were prepared in ethyl acetate and stored in amber glass vials at $-20^{\circ} \mathrm{C}$ in the dark. Ethanol stock solutions (approximately $2 \mathrm{mM}$ ) were prepared from the concentrated stocks, sterile filtered through a $0.2 \mu \mathrm{m}$ syringe filter, and stored in glass vials at $-20^{\circ} \mathrm{C}$ in the dark for use in the retinoidsupplementation studies (described below). The absorbance and spectrum of each sterile retinoid stock was determined with a UV-VIS spectrophotometer, and concentrations calculated using the following absorption coefficients: $44,300 \mathrm{~L} / \mathrm{mol} \times \mathrm{cm}$ at $350 \mathrm{~nm}$ for at-RA in ethanol; $39,800 \mathrm{~L} / \mathrm{mol} \times \mathrm{cm}$ at $354 \mathrm{~nm}$ for $13-c i s-\mathrm{RA}$ in ethanol; 36,500 L/mol $\times \mathrm{cm}$ at $343 \mathrm{~nm}$ for 9-cis-RA in methanol; $46,000 \mathrm{~L} / \mathrm{mol} \times \mathrm{cm}$ at $325 \mathrm{~nm}$ for ROL in ethanol.

\section{Retinoid supplementation studies without cells}

$5 \mathrm{~mL}$ media was supplemented with $0.5 \mu \mathrm{M}$ at-RA, 9-cis RA, 13-cis RA, ROL, or vehicle ( $\leq 0.04 \%$ ethanol, control), and the media was either analyzed immediately or was snap frozen in liquid nitrogen and stored at $-80^{\circ} \mathrm{C}$ until time of analysis. For overnight incubations (18 to $24 \mathrm{~h}$, hereafter referred to as $24 \mathrm{~h}$ ), media was added to cell culture dishes and incubated in the dark at $37^{\circ} \mathrm{C}$ in a humidified atmosphere containing $7.5 \% \mathrm{CO}_{2}$.

\section{Retinoid supplementation studies with cells}

mESCs were seeded in media without retinoids and allowed to settle overnight. The media was replaced with fresh, retinoidsupplemented media. After $24 \mathrm{~h}$ incubation, the media was removed and processed as described above. When cultures were exposed to retinoids for longer than $24 \mathrm{~h}$, the media was replaced with fresh, retinoid-supplemented media every $24 \mathrm{~h}$.

\section{BSA-supplemented media}

In some experiments, BL6 mESC serum-free media was supplemented with $0.5 \mathrm{mg} / \mathrm{ml}$ (Futterman and Heller 1972) or $6 \mathrm{mg} / \mathrm{mlBSA}$ (Quinlan et al., 2005). Dissolution of BSA and mixing with at-RA and ROL were as described (N'soukpoe-Kossi et al., 2007). Retinoid solutions were added drop by drop to BSA-supplemented media
TABLE 1

\section{RECOVERY OF SUPPLEMENTED RETINOIDS FROM R1ES MEDIA AND CELL CULTURES}

\begin{tabular}{|c|c|c|c|c|}
\hline Retinoid added & $\begin{array}{l}\text { Retinoid } \\
\text { analyzed }\end{array}$ & $\begin{array}{c}\text { R1ES Media } \\
\text { No Incubation } \\
\text { Without Cells } \\
\text { (Percent } \\
\text { Recovery) }\end{array}$ & $\begin{array}{c}\text { R1ES Media } \\
24 \text { HR Incubation } \\
\text { Without Cells } \\
\text { (Percent } \\
\text { Recovery) }\end{array}$ & $\begin{array}{l}\text { R1ES Media } \\
24 \text { HR Incubation } \\
\text { With Cells } \\
\text { (Percent } \\
\text { Recovery) }\end{array}$ \\
\hline \multirow[t]{2}{*}{ MEDIA + Vehicle } & at-RA & nd & nd & nd \\
\hline & $\mathrm{ROL}$ & $0.03 \pm 0.01 \mu \mathrm{M}$ & $0.03 \pm 0.01 \mu \mathrm{M}$ & $0.02 \pm 0.00 \mu \mathrm{M}$ \\
\hline \multirow[t]{2}{*}{ MEDIA + at-RA } & at-RA & $\begin{array}{c}0.31 \pm 0.03 \mu \mathrm{M} \\
(61 \%)\end{array}$ & $\begin{array}{c}0.34 \pm 0.06 \mu \mathrm{M} \\
(69 \%)\end{array}$ & $\begin{array}{c}0.06 \pm 0.01 \mu \mathrm{M} \\
(11 \%)\end{array}$ \\
\hline & Pooled RA & $\begin{array}{c}0.33 \pm 0.01 \mu \mathrm{M} \\
(66 \%)\end{array}$ & $\begin{array}{c}0.38 \pm 0.06 \mu \mathrm{M} \\
(76 \%)\end{array}$ & $\begin{array}{c}0.06 \pm 0.01 \mu \mathrm{M} \\
(12 \%)\end{array}$ \\
\hline MEDIA + ROL & ROL & $\begin{array}{c}0.30 \pm 0.00 \mu \mathrm{M} \\
(59 \%)\end{array}$ & $\begin{array}{c}0.28 \pm 0.05 \mu \mathrm{M} \\
(55 \%)\end{array}$ & $\begin{array}{c}0.18 \pm 0.03 \mu \mathrm{M} \\
(34 \%)\end{array}$ \\
\hline \multirow[t]{2}{*}{ MEDIA + 9-cis-RA } & 9-cis-RA & $\begin{array}{c}0.37 \pm 0.07 \mu \mathrm{M} \\
(74 \%)\end{array}$ & $\begin{array}{c}0.34 \pm 0.04 \mu \mathrm{M} \\
(68 \%)\end{array}$ & $\begin{array}{c}0.15 \pm 0.01 \mu \mathrm{M} \\
(30 \%)\end{array}$ \\
\hline & Pooled RA & $\begin{array}{c}0.37 \pm 0.07 \mu \mathrm{M} \\
(74 \%)\end{array}$ & $\begin{array}{c}0.35 \pm 0.05 \mu \mathrm{M} \\
(70 \%)\end{array}$ & $\begin{array}{c}0.15 \pm 0.01 \mu \mathrm{M} \\
(30 \%)\end{array}$ \\
\hline \multirow[t]{2}{*}{ MEDIA + 13-cis-RA } & 13-cis-RA & $\begin{array}{c}0.35 \pm 0.04 \mu \mathrm{M} \\
(69 \%)\end{array}$ & $\begin{array}{c}0.32 \pm 0.03 \mu \mathrm{M} \\
(61 \%)\end{array}$ & $\begin{array}{c}0.22 \pm 0.02 \mu \mathrm{M} \\
(45 \%)\end{array}$ \\
\hline & Pooled RA & $\begin{array}{c}0.37 \pm 0.04 \mu \mathrm{M} \\
(74 \%)\end{array}$ & $\begin{array}{c}0.34 \pm 0.03 \mu \mathrm{M} \\
(68 \%)\end{array}$ & $\begin{array}{c}0.25 \pm 0.02 \mu \mathrm{M} \\
(50 \%)\end{array}$ \\
\hline
\end{tabular}

Mean \pm s.d. concentration and mean percent recovery for 3 independent samples are given. nd=not detectable.

with constant stirring to produce desired final concentrations. Media was gently rocked for $15 \mathrm{~min}$ at room temperature to allow time for the retinoids to bind to the BSA and to ensure media homogeneity. Three different media preps each were prepared for at-RA and for ROL. $5 \mathrm{~mL}$ from each of the preparations was snap frozen (0h samples) and stored at $-80^{\circ} \mathrm{C}$ until the day of analysis. Another $5 \mathrm{~mL}$ from each sample was incubated in cell culture dishes for $24 \mathrm{~h}$.

\section{HPLC method}

HPLC analyses were carried out using an Agilent Technologies 1100 HPLC system as described in (Asson-Batres et al., 2009). Separation was with an Agilent Technologies Zorbax Eclipse XDB, $3 \mathrm{~mm}$ mesh, $150 \mathrm{~mm}$ C18 column. Solvent Awas $40 \mathrm{mM}$ ammonium acetate, $70 \mathrm{mM}$ acetic acid in water; solvent B was acetonitrile/ methanol/n-butanol (80:4:3) containing $40 \mathrm{mM}$ ammonium acetate, $70 \mathrm{mM}$ acetic acid. A gradient was run from $80 \%$ solvent $B$ to $100 \% \mathrm{~B}$ for $15 \mathrm{~min}$, held at $100 \% \mathrm{~B}$ for $5 \mathrm{~min}$, and returned to $80 \%$ solvent B for $5 \mathrm{~min}$, with a $10 \mathrm{~min}$ post run equilibration. Flow rate was $0.25 \mathrm{~mL} / \mathrm{min}$. Column temperature was $30^{\circ} \mathrm{C}$. Detection was with a photodiode array detector (DAD) set to collect at 345 (maximal absorbance of RA), 325 (maximal absorbance of ROL), and 250 (reference) $\mathrm{nm}$. Bandpass widths for DAD spectra were set at $16 \mathrm{~nm}$. Samples were set up in a thermostatted compartment maintained at $20^{\circ} \mathrm{C}$, and $10 \mu \mathrm{L}$ injections were made with an automated sample injector. After each day's analyses, the column was washed overnight with $10 \%$ acetonitrile/90\% water, followed by a wash with $90 \%$ acetonitrile/10\% water.

\section{Extraction of retinoids from cell culture media}

$0.5 \mathrm{~mL}$ cell culture media was brought to a final concentration of $0.2 \mathrm{M}$ with acetic acid and mixed by vortexing with $1.0 \mathrm{~mL}$ ice cold $100 \%$ ethanol. Two to three volumes of hexane were added, and 
the sample was vortexed for 2 min and centrifuged at $4000 \mathrm{~g} \times 20$ $\min \times 4^{\circ} \mathrm{C}$. The organic layer was transferred to a glass tube and dried under a gentle stream of argon gas. $100 \mu \mathrm{L}$ HPLC solvent $\mathrm{B}$ was added to the dried residue. The samples were vortexed briefly, allowed to stand at room temperature for $5 \mathrm{~min}$, and the resuspended sample was transferred to an autosampler vial.

\section{Standard curves and sample concentrations}

Standard curves were generated by separating 5-6 concentrations of each retinoid. Peak areas were plotted against concentration, and the best fit line was determined by least squares regression analysis. These standard curves were used to calculate daily standard and sample recoveries: at-RA, $Y=92 x-7\left(\mathrm{r}^{2}=\right.$ 0.999); ROL $Y=79 x+16\left(r^{2}=0.999\right) ; 9$-cis-RA, $Y=90 x-16$ $\left(r^{2}=0.999\right)$; 13-cis- RA, $Y=83 x-9\left(r^{2}=0.999\right)$.

Sample retinoid peaks were identified by comparing their retention times and spectra with those of authentic standards. An appropriate internal standard to correct for normal day-to-day variability in chromatographic separations of RA isomers was not available for these analyses. Thus, unextracted retinoid standards were included in all sample runs, and the sample recoveries of each run were corrected using the percent recovery of the appropriate standard for that day. Retinoid standards for each analysis were freshly prepared on the day of the run by diluting ethanol

TABLE 2A

RECOVERY OF SUPPLEMENTED RETINOIDS FROM BL6 SERUM-FREE MEDIA AND CELL CULTURES*

\begin{tabular}{|c|c|c|c|c|}
\hline Retinoid added & $\begin{array}{l}\text { Retinoid } \\
\text { analyzed }\end{array}$ & $\begin{array}{l}\text { BL6 Media } \\
\text { No Incubation } \\
\text { Without Cells } \\
\text { (Percent Recovery) }\end{array}$ & $\begin{array}{c}\text { BL6 Media } \\
24 \text { HR Incubation } \\
\text { Without Cells } \\
\text { (Percent Recovery) }\end{array}$ & $\begin{array}{c}\text { BL6 Media } \\
24 \text { HR Incubation } \\
\text { With Cells } \\
\text { (Percent } \\
\text { Recovery) }\end{array}$ \\
\hline MEDIA + Vehicle & $\mathrm{ROL}$ & nd & nd & nd \\
\hline \multirow[t]{2}{*}{ MEDIA + at-RA } & at-RA & $\begin{array}{c}0.28 \pm 0.01 \\
(55 \%)\end{array}$ & $\begin{array}{l}0.13 \dagger \\
(27 \%)\end{array}$ & $\begin{array}{c}0.04 \pm 0.03 \mu \mathrm{M} \\
(8 \%)\end{array}$ \\
\hline & Pooled RA & $\begin{array}{c}0.31 \pm 0.01 \\
(62 \%)\end{array}$ & $\begin{array}{l}0.29 \dagger \\
(58 \%)\end{array}$ & $\begin{array}{c}0.12+0.03 \mu \mathrm{M} \\
(24 \%)\end{array}$ \\
\hline MEDIA + ROL & ROL & $\begin{array}{c}0.15 \pm 0.02 \\
(30 \%)\end{array}$ & $\begin{array}{c}0.02 \pm 0.01 \\
(4 \%)\end{array}$ & nd $†$ \\
\hline
\end{tabular}

Mean \pm s.d. concentration and mean percent recovery for 3 independent samples are given. ${ }^{*} \mathrm{~A}$ proprietary amount of ROL is present in the chemically defined serum-free media that was used to grow BL6 mESCs; however, this amount was not detectable by our method of HPLC analysis. $\dagger \mathrm{N}=2$. nd=not detectable

TABLE 2B

\section{RECOVERY OF SUPPLEMENTED RETINOIDS FROM BL6 SERUM-FREE MEDIA SUPPLEMENTED WITH BSA}

\begin{tabular}{|c|c|c|c|c|}
\hline Retinoid added & $\begin{array}{l}\text { Retinoid } \\
\text { analyzed }\end{array}$ & $\begin{array}{c}\text { BL6 Media + } \\
6 \mathrm{mg} / \mathrm{ml} \text { BSA } \\
\text { No Incubation } \\
\text { Without Cells } \\
\text { (Percent } \\
\text { Recovery) }\end{array}$ & $\begin{array}{c}\text { BL6 Media + } \\
6 \mathrm{mg} / \mathrm{ml} \text { BSA } \\
24 \mathrm{HR} \text { Incubation } \\
\text { Without Cells } \\
\text { (Percent } \\
\text { Recovery) }\end{array}$ & $\begin{array}{c}\text { BL6 Media + } \\
0.5 \mathrm{mg} / \mathrm{ml} \text { BSA } \\
24 \mathrm{HR} \text { Incubation } \\
\text { Without Cells } \\
\text { (Percent Recovery) }\end{array}$ \\
\hline \multirow[t]{2}{*}{ MEDIA + at-RA } & at-RA & $\begin{array}{c}0.28 \pm 0.08 \\
(56 \%)\end{array}$ & $\begin{array}{c}0.31 \pm 0.03 \\
(62 \%)\end{array}$ & $\begin{array}{c}0.16 \pm 0.01 \\
(32 \%)\end{array}$ \\
\hline & Pooled RA & $\begin{array}{c}0.28 \pm 0.08 \\
(56 \%)\end{array}$ & $\begin{array}{c}0.44 \pm 0.03 \\
(88 \%)\end{array}$ & $\begin{array}{c}0.27 \pm 0.04 \\
(54 \%)\end{array}$ \\
\hline MEDIA + ROL & ROL & $\begin{array}{c}0.34 \pm 0.01 \\
(68 \%)\end{array}$ & $\begin{array}{c}0.18 \pm 0.03 \\
(36 \%)\end{array}$ & $\begin{array}{c}0.09 \pm 0.03 \\
(18 \%)\end{array}$ \\
\hline
\end{tabular}

Mean \pm s.d. concentration and mean percent recovery for 3 independent samples are given. stocks to $2.5 \mathrm{uM}$ with solvent buffer. This concentration was the expected theoretical concentration of the extracted samples at the point of injection onto the HPLC column.

\section{Image analysis}

Brightfield images of living cells were acquired with an OptixCam digital camera mounted in the eyepiece of a Hund Wetzler inverted microscope. Images were edited for presentation in Adobe Photoshop CS2. HPLC traces were obtained with ChemStations ver 10.1 and exported to Adobe Illustrator CS2. Layers were merged into a single image and saved as TIFF files at $300 \mathrm{dpi}$ resolution.

\section{Statistical analysis}

Preliminary studies were carried out to design the formal test of retinoid stability that ultimately yielded results reported in Tables 1 and 2. Three independent analyses were carried out for each control and experimental treatment group. All similar samples were extracted and analyzed on the same day. Values in Tables 1 and 2 are the mean \pm one standard deviation of the three measurements for the indicated groups. In two cases, one of the three samples was judged to be artifactual, reported in Table 2 (where sample size, $\mathrm{N}=2$ ). Additional samples prepared and analyzed on another day confirmed the results (data not shown).

\section{Results}

\section{Effects of at-retinoic acid (RA) and retinol (ROL) on mouse embryonic stem cells (mESCs)}

The retinoid stocks used in this study were stored in ethanol, and ethanol was added as a vehicle control to mESC cultures. Embryonic stem cells grown in media supplemented with $\leq 0.04 \%$ ethanol for $24 \mathrm{~h}$ (Fig. 1, group I) or 48 h (Fig. 1, group II) retained the morphologic features of undifferentiated, pluripotent stem cell colonies (arrowheads, Fig. 1 A,E,I,M). BL6 mESCs exposed to 0.1 to $10 \mu \mathrm{M}$ at-RA in chemically defined, serum-free media displayed a differentiated morphology at $24 \mathrm{~h}$ and $48 \mathrm{~h}$ (arrows, Fig. $1 \mathrm{~B}-\mathrm{D}$ and $1 \mathrm{~J}-\mathrm{L}$ ). Other studies carried out in the lab (to be published elsewhere) have confirmed that undifferentiated BL6 mESCs express the pluripotent markers, OCT3/4 and SSEA I, and when grown in the concentrations of at-RA shown in Fig. 1, do express differentiation markers, including the neuron lineage markers, neuron specific $\beta$-tubulin III and GAP-43. The results shown in Fig. 1 portray effects of at-RA on BL6 mESCs maintained in serum free media. Similar results were observed with R1 mESCs maintained in DMEM supplemented with FBS (data not shown).

BL6 mESCs grown in serum free media supplemented with 0.1 and $1 \mu \mathrm{M}$ ROL also exhibited a differentiated morphology after 24 and 48h exposure (Fig. 1 F-G and 1 N-O). BL6 mESCs exposed to $10 \mu \mathrm{M}$ ROL died within $2 \mathrm{~h}$ exposure to the retinoid (Fig. $1 \mathrm{H}$ and $1 \mathrm{P}$ ).

\section{Analysis of retinoids in cell culture media}

To investigate whether at-RA is stable in media maintained under cell culture conditions and to determine whether at-RA is depleted or broken down after $24 \mathrm{~h}$, at-RA status was monitored in media using an HPLC method that was designed for optimal recovery of acidic retinoids (Asson-Batres et al., 2009). This method also recovers ROL. The data indicated that retinoid stability was affected by the media formulation. 

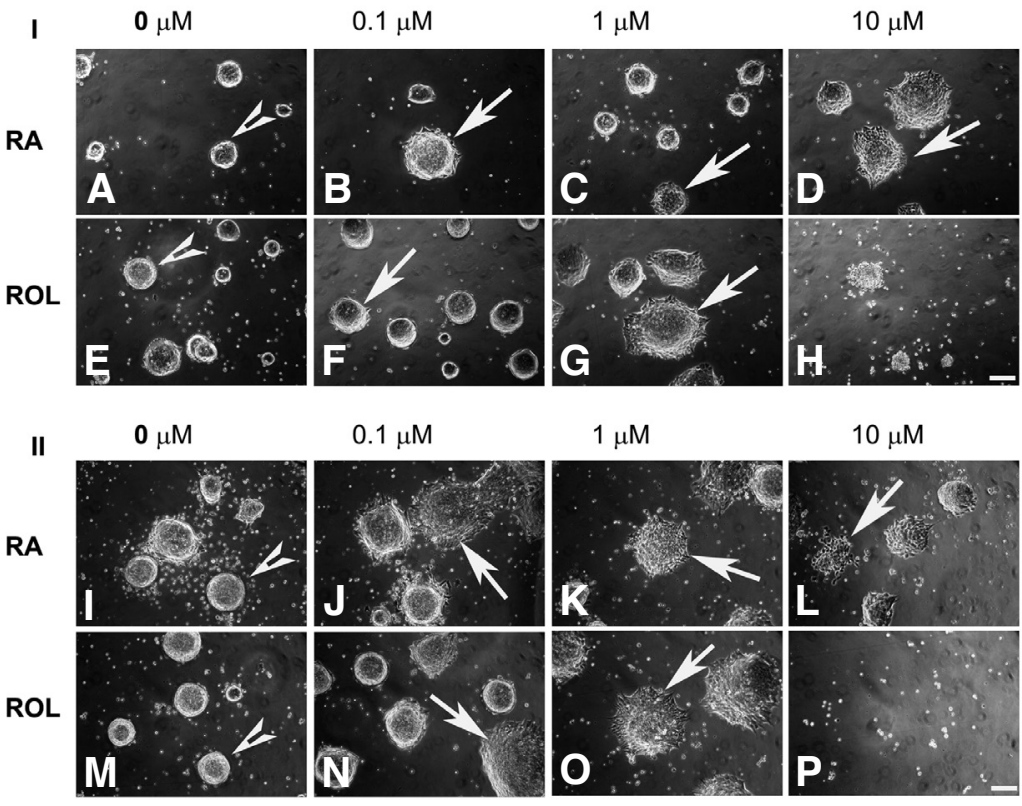

Fig. 1. BL6 mouse embryonic stem cells (mESCs) exposed to increasing concentrations of at-retinoic acid (at-RA) or retinol (ROL) in chemically defined, serum free media for $\mathbf{2 4 h}$ (I) and $48 \mathrm{~h}$ (II) exhibit a differentiated morphology. ESGRO Complete Plus media was supplemented with vehicle (A,E, I,M), 0.1, 1, or $10 \mu \mathrm{M}$ at-RA (B, J; C,K; D, L) (respectively), or with 0.1, 1, or $10 \mu M R O L$ (F,N; G,0; H,P) (respectively). Brightfield images were acquired with an OptixCam digital camera attached to a Hund Wetzlar inverted microscope. Arrowheads indicate undifferentiated cell colonies; arrows indicate colonies that are undergoing differentiation. Note that $10 \mu \mathrm{M} \mathrm{ROL} \mathrm{kills} \mathrm{cells} \mathrm{within} 2 \mathrm{~h}$ of exposure. Scale bar represents $100 \mu \mathrm{m}$.

\section{Retinoids in serum-supplemented media}

R1 mESC media supplemented with vehicle had no detectable RA, but did have 0.01 to $0.03 \mu \mathrm{M}$ ROL (Table 1; Fig. 2 A,C,D). Since ROL is present in FBS, this latter result was expected. The extraction efficiency for retinoids added to control (unincubated, Oh) mESC serum-supplemented media was approximately $60-70 \%$ for all three RA isomers and ROL.

Maintenance of retinoid-supplemented media (without cells) under the increased temperature and humidified air conditions associated with cell culture had no effect on the recovery of any of the RA species or ROL, and, there was little or no isomerization of added at-RA, 9-cis-RA, 13-cis-RA or ROL (Table 1 and Fig. 2). When cells were incubated in media with added retinoids, there was a notable reduction in the levels of the retinoids in the spent media after $24 \mathrm{~h}$. The greatest reduction was in at-RA levels, which were reduced to approximately $20 \%$ of those recovered from unincubated $(\mathrm{Oh})$ and cell-free incubated media (24h), followed by 9 -cis-RA and ROL levels, which were reduced to approximately $50 \%$ of those in cell-free media (Table 1 and Figs. 2 B,C), and 13-cis-RA levels, which were least affected, with measured levels in spent media only reduced to about $70 \%$ of levels in cell-free, unincubated and incubated media (Table 1 and Fig. 2D).

\section{Retinoids in serum-free media}

Fifty five percent of at-RA added to unincubated BL6 media was recovered as a single peak eluting at the same time as authentic at-RA standard (Table 2A, Fig. 3A). After 24h incubation without cells, $27 \%$ at-RA was recovered (Table 2A). Growth of cells in the at-RA supplemented media further reduced recovery levels to $8 \%$ of the original amount added (Table 2A, Fig. 3B). Pooled RA recovery data indicate there was little isomerization of added at-RA in the unincubated media, but $24 \mathrm{~h}$ incubation with or without cells led to $50 \%$ isomerization of at-RA (Table $2 \mathrm{~A}$ ).

When serum-free media was supplemented with ROL, recovered ROL levels declined after overnight incubation even in the absence of cells (Table 2A). This loss of ROL was accompanied by the recovery of unidentified species in the HPLC trace (compare Figs. 2D and E). Growth of cells in the ROL-supplemented serum-free media further reduced recoverable ROL to non-detectable levels (Table 2A). Albumin, a component of FBS, that has the capacity to bind lipophilic molecules, including retinoids (Futterman and Heller 1972; Quinlan et al., 2005), was added to BL6 mESC media in some experiments to determine whether it would improve the stability of at-RA and $\mathrm{ROL}$ in this serum free medium. BL6 media supplemented with $6 \mathrm{mg} / \mathrm{ml} \mathrm{BSA}$, a concentration equivalent to that found in the R1
A

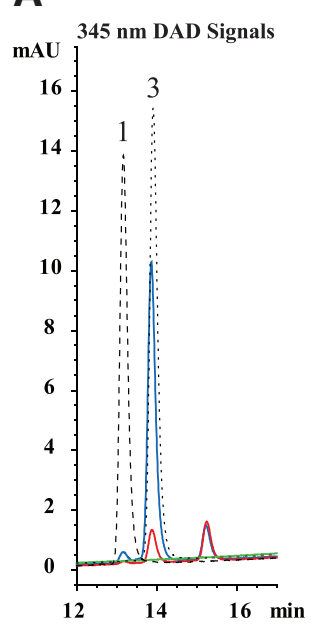

B

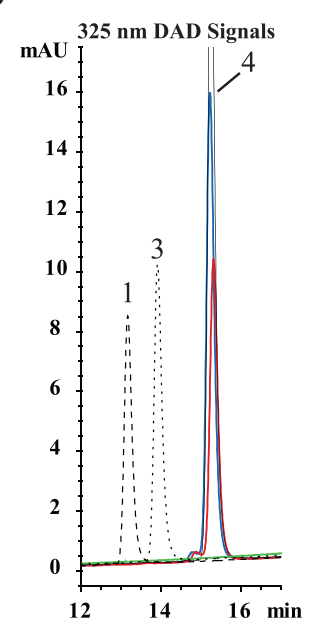

C

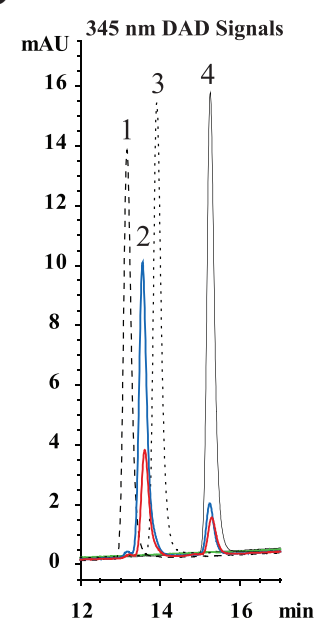

\section{D}

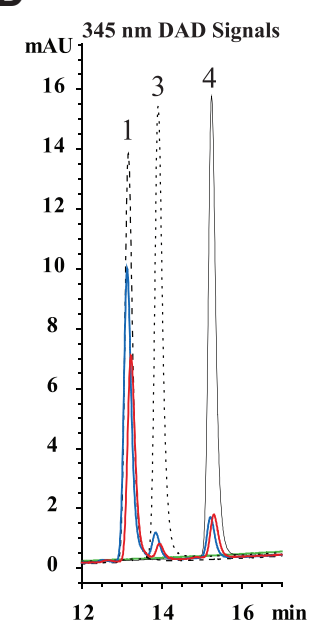

Fig. 2. R1 mESCs metabolize retinoids. Retinoids were added to serum-supplemented media and incubated at $37^{\circ} \mathrm{C}$ for $24 \mathrm{~h}$ with (red traces) and without (blue traces) R1 mESCs. (A) at-RA-supplemented media. (B) ROL-supplemented media. (C) 9-cis-RA-supplemented media. (D) 13-cis-RA-supplemented media. Standardpeaks are 13-cis-RA (1, dashed trace), at-RA (3, dotted trace), and ROL (4, solid black trace), respectively. 9-cis-RA eluted at 13.6 min (sample peak labeled 2 in C). Blank traces are shown in green. Signals were detected at 345 and $325 \mathrm{~nm}$ using a diode array detector (DAD) as indicated. 
mESC serum-supplemented media had a protective effect on the stability and recovery of at-RA after incubation for $24 \mathrm{~h}$ without cells (Table 2B; Fig. 3C). This concentration of BSA also increased the recovery of ROL from unincubated media. However, after $24 \mathrm{~h}$ incubation under cell culture conditions, $6 \mathrm{mg} / \mathrm{mL}$ BSA only partially protected ROL (Table 2B; Fig. 3F). Supplementation of

A

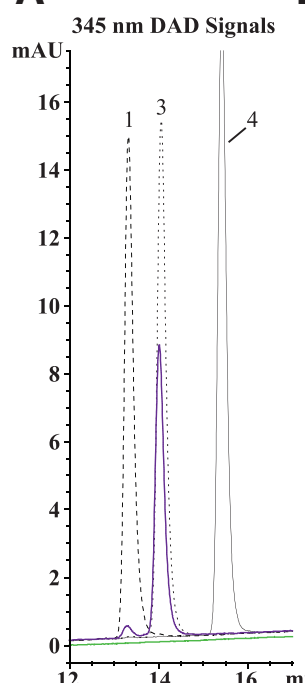

B
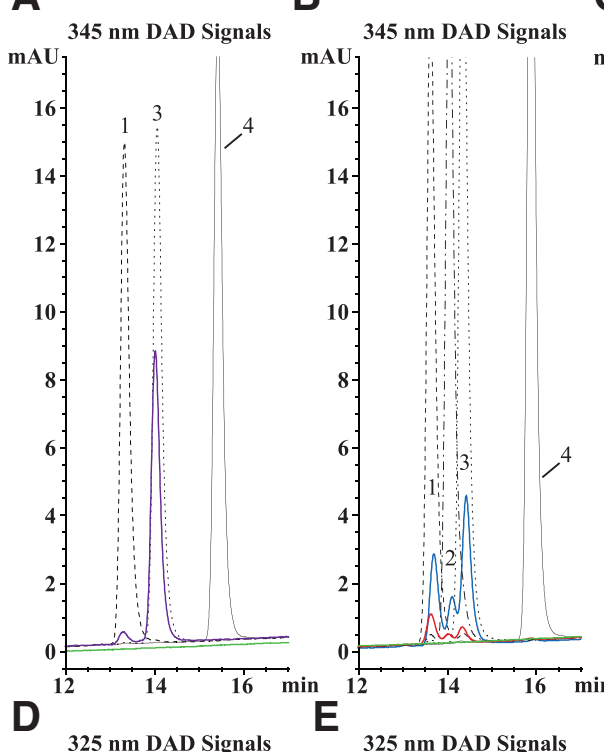

E
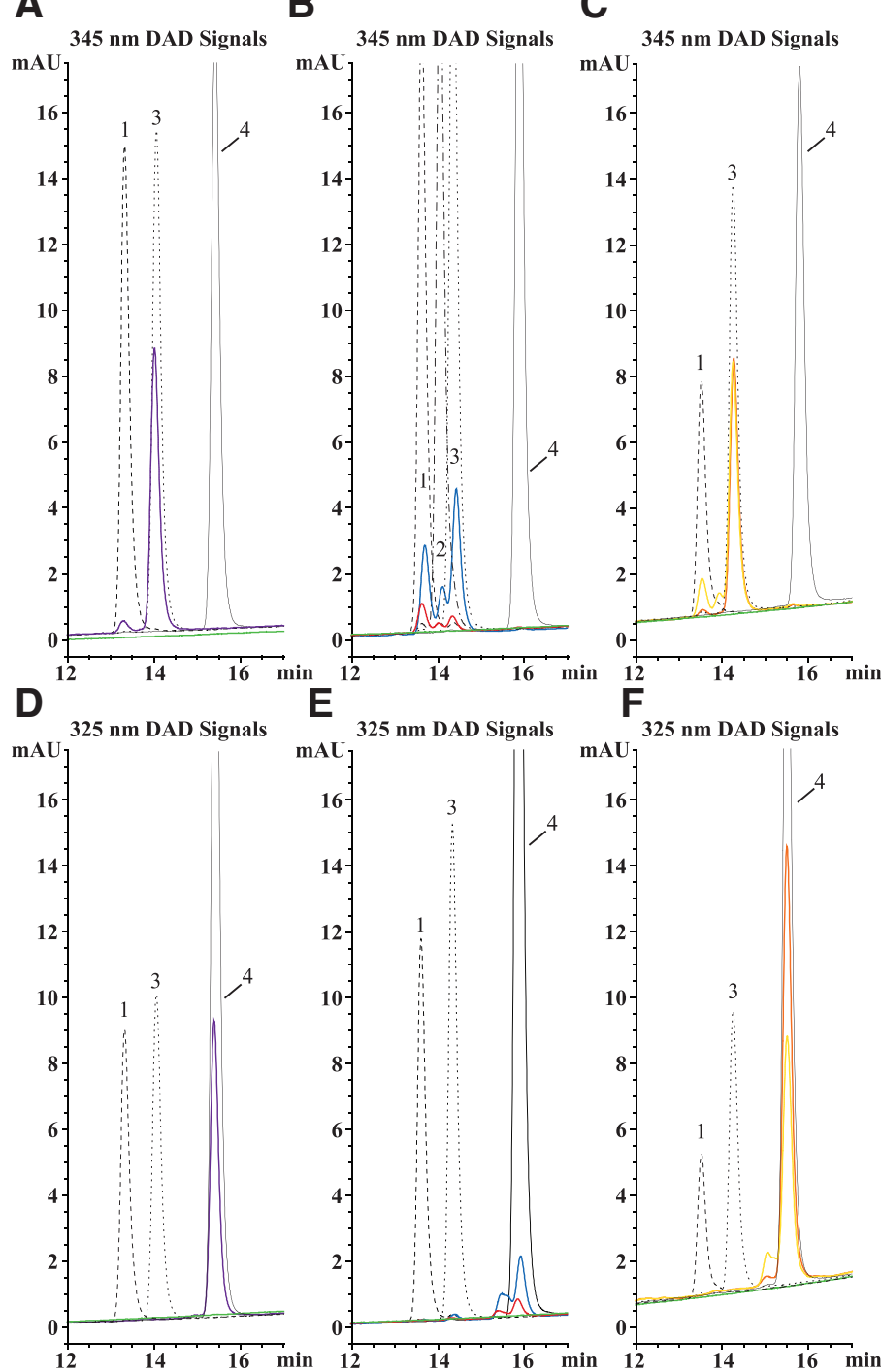

Fig. 3. Retinoids are unstable in serum free media. Retinoids were added to chemically defined, serum,-free media and analyzed immediately (Oh) or incubated overnight with and without BL6 mESC. (A) at-RA-supplemented media without cells, Oh, purple trace. (B) at-RA-supplemented media incubated for $24 \mathrm{~h}$ with (red trace) and without cells (blue trace). (C) Media supplemented with at-RA and $6 \mathrm{mg} / \mathrm{ml}$ BSA incubated without cells, Oh (orange trace) or $24 \mathrm{~h}$ (yellow trace). (D) ROL-supplemented media without cells, Oh (purple trace). (E) ROL-supplemented media incubated for $24 \mathrm{~h}$ with (red trace) and without cells (blue trace). (F) Media supplemented with ROL and $6 \mathrm{mg} / \mathrm{ml}$ BSA incubated without cells, Oh (orange trace) or $24 h$ (yellow trace). Standard peaks shown in each panel are 13-cis-RA (1, dashed trace), at-RA (3, dotted trace), and ROL (4, solid black trace), respectively. 9-cis-RA (2, dot-dash trace) standard peak is shown in panel $B$. Blank traces are shown in green. Signals were detected at 345 and $325 \mathrm{~nm}$ using a diode array detector (DAD) as indicated. serum-free media with $0.5 \mathrm{mg} / \mathrm{mL}$ BSA had no stabilizing effect on any of the retinoids analyzed (Table $2 \mathrm{~B}$ ).

\section{Discussion}

The purpose of this study was to determine whether retinoids are stable under cell culture conditions. Media with and without serum was supplemented with retinoids and incubated with and without cells, and retinoids were extracted and analyzed using HPLC. Special handling of retinoids was required to ensure the results reported here. All operations from the preparation of retinoid stocks to addition of retinoids to cultures in the cell culture hood were conducted under yellow light. When viewing cells using brightfield microscopy, a yellow filter was inserted in the light path to block out light that could photodamage the retinoids. Culture dishes were wrapped in aluminum foil and kept in the dark during incubation. Retinoid stocks were stored at $-20^{\circ} \mathrm{C}$ in the dark and their concentrations and spectra were checked routinely using a spectrophotometer and their integrity was verified using HPLC.

Surprisingly, there was little loss or isomerization of at-RA, 9-cisRA, 13-cis-RA, or ROL in serum-supplemented media (without cells) exposed to cell culture conditions for $24 \mathrm{~h}$. Recoveries of at-RA and 13-cis-RA obtained in this study were generally similar or better than those of Tsukada et al., (Tsukada et al., 2002), who reported recoveries of approximately $65 \%$ and $78 \%$ of at-RA and 13-cis-RA, respectively, from unincubated serum-supplemented media, and recoveries of $55 \%$ for at-RA, but only $30 \%$ for $13-$ cis$\mathrm{RA}$, from serum-supplemented media maintained under cell culture conditions without cells for $24 \mathrm{~h}$.

The stability of both at-RA and ROL were determined to be greatly reduced in serum-free media. Recovery of at-RA from unincubated, serum-free media control samples (55\%) were comparable to recoveries from serum-supplemented media (61\%). However, in contrast with recoveries of $69 \%$ at-RA from cell-free, serum-supplemented media after $24 \mathrm{~h}$ incubation, only $27 \%$ of at-RA was recovered from serum-free media incubated without cells. Over half of the total RA detected in these $24 \mathrm{~h}$ serum-free media samples showed up as isomerized forms of RA. Only 30\% of ROL was recovered from unincubated, serum-free media, and this amount dropped to $4 \%$ after $24 \mathrm{~h}$ incubation without cells, with apparent loss of ROL and appearance of unidentified products on the HPLC trace.

Protein has been shown to stabilize retinoids (Klaassen et al., 1999) (N'soukpoe-Kossi et al., 2007). To test whether the greater stability of at-RA and ROL in serum-supplemented media versus serum-free media is due to the presence of FBS, BSA was added to retinoid-supplemented, serum-free media samples. Adding $6 \mathrm{mg} /$ $\mathrm{mL} B S A$ to serum-free media resulted in recoveries of at-RA from $24 \mathrm{~h}$ incubated samples (no cells present) that were comparable to those obtained with extractions from serum-supplemented media (62\% versus $69 \%$ recovery, respectively). Unlike at-RA, the recovery of ROL from BSA-supplemented, serum-free media incubated for $24 \mathrm{~h}$ (no cells present) was only partial, increasing only from $4 \%$ to $36 \%$. The results confirm a stabilizing effect of protein on retinoids in growth media and, further, show that stabilization is dependent on protein concentration $(0.5 \mathrm{mg} / \mathrm{ml}$ BSA was ineffective) and retinoid type (e.g., $\mathrm{ROL}$ was less stable than at-RA).

Addition of at-RA to serum-supplemented growth media induced differentiation of serum-adapted R1 mESC, and the levels of at- 
RA, 9-cis-RA, 13-cis-RA, and ROL in serum-supplemented spent media decreased to $11 \%, 30 \%, 45 \%$, and $34 \%$ of the original amount added, respectively after $24 \mathrm{~h}$. These results suggest that $\mathrm{R} 1 \mathrm{mESC}$ took up each of the retinoid species, with greatest uptake evident in cells exposed to at-RA, followed by 9 -cis-RA and ROL. Internalization of retinoids by $\mathrm{R} 1 \mathrm{mESC}$ is consistent with reports that $A B 1$ ESC take up large amounts of $\left[{ }^{3} \mathrm{H}\right] \mathrm{RA}$ from the medium within minutes to hours of exposure (Chen and Gudas 1996) and work showing that the half life of RA taken up from the medium by cultured cells ranges from 3.5 to $6 \mathrm{~h}$ (Williams and Napoli 1985; Redfern and Todd 1988). As shown here, cells deplete retinoids after $24 \mathrm{~h}$ incubation and thus, need to be refed daily with freshly prepared retinoid-supplemented growth media during the course of a multiple day exposure experiment.

Regardless of the decreased stability of retinoids in serum-free, chemically defined media, BL6 mESC still differentiated in response to $0.1 \mathrm{uM}$ to $10 \mathrm{uM}$ at-RA. Several explanations of this result are possible. (1), at-RA may induce differentiation within hours of exposure before significant amounts of degradation or isomerization of at-RA occurs; (2) the small amount of non-degraded at-RA still present in serum-free media after $24 \mathrm{~h}$ may be sufficient to promote or maintain differentiation processes since RARs are activated by $\mathrm{nM}$ amounts of at-RA; or (3) other RA isomers may promote or contribute to cell differentiation processes.

BL6 mESC grown in chemically defined serum free media supplemented with 0.1 to $1 \mathrm{uM}$ ROL were also induced to differentiate. These results are in contrast with those of Chen \& Khillan (Chen and Khillan 2010), who have reported that ROL suppresses differentiation and maintains pluripotency in mESC by a mechanism that does not involve RA signaling. Unlike RA-supplemented cultures, mESC exposed to 10uM ROL died within hours for unexplained reasons. Zouboulis et al., (Zouboulis et al., 1999) also observed that $10 \mathrm{uM} \mathrm{ROL}$ was toxic to cultured cells, reporting that cell proliferation was essentially inhibited at this concentration in human keratinocytes.

\section{Acknowledgments}

We thank Linh Tran and Christopher Norwood for technical support. Funding for grant NIH/NIGMS/MBRS/SCORE SO6 GM 008092 to MAAB was used to support these studies.

\section{References}

ASSON-BATRES MA, SMITH WB, CLARK G (2009). Retinoic acid is present in the postnatal rat olfactory organ and persists in vitamin A--depleted neural tissue. $J$ Nutr 139: 1067-1072
BAHARVAND H, MEHRJARDI NZ, HATAMI M, KIANI S, RAO M, HAGHIGHI MM (2007) Neural differentiation from human embryonic stem cells in a defined adherent culture condition. Int J Dev Biol 51:371-378

CARICASOLE A, WARD-VAN OD, ZEINSTRA L, VAN DEN EIJNDEN-VAN RAAIJ, MUMMERY C (2000) Bone morphogenetic proteins (BMPs) induce epithelial differentiation of NT2D1 human embryonal carcinoma cells. Int J Dev Biol44:443-450

CHEN AC, GUDAS LJ (1996). An analysis of retinoic acid-induced gene expression and metabolism in AB1 embryonic stem cells. J Biol Chem 271: 14971-14980.

CHEN L, KHILLAN JS (2010). A novel signaling by vitamin A/retinol promotes self renewal of mouse embryonic stem cells by activating PI3K/Akt signaling pathway via insulin-like growth factor-1 receptor. Stem Cells 28: 57-63.

CRNEK V, VLAHOVIC M, SKREB N (1991) Retinoic acid can change normal differentiation of rat egg-cylinders cultured in vitro. Int J Dev Biol 35:197-202

DUONG V, ROCHETTE-EGLY C (2011) The molecular physiology of nuclear retinoic acid receptors. From health to disease. Biochim Biophys Acta 1812:1023-1031

FUTTERMAN S, HELLER J (1972). The enhancement of fluorescence and the decreased susceptibility to enzymatic oxidation of retinol complexed with bovine serum albumin, -lactoglobulin, and the retinol-binding protein of human plasma. $J$ Biol Chem 247: 5168-5172.

GUBLER ML, SHERMAN MI (1985). Metabolism of retinoids by embryonal carcinoma cells. J Biol Chem 260: 9552-9558.

GUDAS LJ, WAGNER JA (2011). Retinoids regulate stem cell differentiation. J Cell Physiol 226: 322-330.

KLAASSEN I, BRAKENHOFF RH, SMEETS SJ, SNOW GB, BRAAKHUIS BJ (1999). Considerations for in vitro retinoid experiments: importance of protein interaction. Biochim Biophys Acta 1427: 265-275.

N'SOUKPOE-KOSSI CN, SEDAGHAT-HERATI R, RAGI C, HOTCHANDANI S, TAJMIR-RIAHI HA (2007). Retinol and retinoic acid bind human serum albumin: stability and structural features. Int J Biol Macromol 40: 484-490.

NOY N (1992). The ionization behavior of retinoic acid in aqueous environments and bound to serum albumin. Biochim Biophys Acta 1106: 151-158.

QUINLAN GJ, MARTIN GS, EVANS TW (2005). Albumin: biochemical properties and therapeutic potential. Hepatology 41: 1211-1219

REDFERN CP, TODD C (1988). The effects of retinoic acid on rat epidermal cells in vitro: changes in patterns of protein phosphorylation in relation to growth and differentiation. Exp Cell Res 174: 367-377

STRICKLAND S, MAHDAVI V (1978). The induction of differentiation in teratocarcinoma stem cells by retinoic acid. Cell 15: 393-403.

SZUTS EZ, HAROSI FI (1991). Solubility of retinoids in water. Arch Biochem Biophys 287: $297-304$

TSUKADA M, SCHRODER M, SELTMANN H, ORFANOS CE, ZOUBOULIS CC (2002). High albumin levels restrict the kinetics of 13-cis retinoic acid uptake and intracellular isomerization to all-trans retinoic acid and inhibit its anti-proliferative effect on SZ95 sebocytes. J Invest Dermatol 119: 182-185.

WILLIAMS JB, NAPOLI JL (1985). Metabolism of retinoic acid and retinol during differentiation of F9 embryonal carcinoma cells. Proc NatlAcad SciUSA 82: 4658-4662.

ZOUBOULIS CC, SELTMANN H, SASS JO, RUHL R, PLUM C, HETTMANNSPERGER U, BLUME-PEYTAVI U, NAU H, ORFANOS CE (1999). Retinoid signaling by all-trans retinoic acid and all-trans retinoyl-beta-D-glucuronide is attenuated by simultaneous exposure of human keratinocytes to retinol. $J$ Invest Dermatol 112: 157-164. 


\section{Further Related Reading, published previously in the Int. J. Dev. Biol.}

Neural differentiation from human embryonic stem cells in a defined adherent culture condition

Hossein Baharvand, Narges-Zare Mehrjardi, Maryam Hatami, Sahar Kiani, Mahendra Rao and Mahdi-Montazer Haghighi Int. J. Dev. Biol. 51: 371 - 378 (2007)

X-chromosome inactivation in differentiating mouse embryonic stem cells carrying X-linked GFP and lacZ transgenes Shirin Farivar, Shinpei Yamaguchi, Michihiko Sugimoto and Nobuo Takagi,

Int. J. Dev. Biol. 48: 629 - 635 (2004)

Bone morphogenetic proteins (BMPs) induce epithelial differentiation of NT2D1 human embryonal carcinoma cell A Caricasole, D Ward-van Oostwaard, L Zeinstra, A van den Eijnden-van Raaij and C Mummery Int. J. Dev. Biol. 44: 443 - 450 (2000)

Stra3/lefty, a retinoic acid-inducible novel member of the transforming growth factor-beta superfamily M Oulad-Abdelghani, C Chazaud, P Bouillet, M G Mattei, P Dollé and P Chambon,

Int. J. Dev. Biol. 42: 23 - 32 (1998)

Caudalization by retinoic acid is correlated with inhibition of cell population growth and expansion of chick blastoderms cultured in vitro

S P Modak, S K Ghatpande, R K Rane and L Mulherkar

Int. J. Dev. Biol. 37: 601 - 607 (1993)

Retinoic acid can change normal differentiation of rat egg-cylinders cultured in vitro

V Crnek, M Vlahovic and N Skreb

Int. J. Dev. Biol. 35: 197 - 202 (1991)

5 yr ISI Impact Factor $(2010)=2.961$

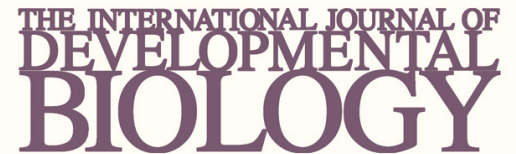

Volume 54 Nos. $6 / 7$
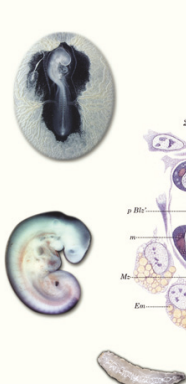

Developmental Hematopoiesis
Special Issue
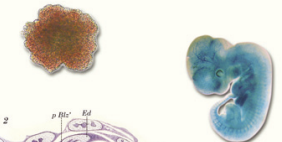
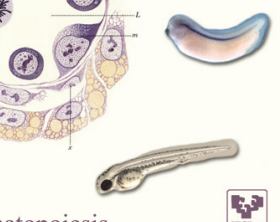

incher
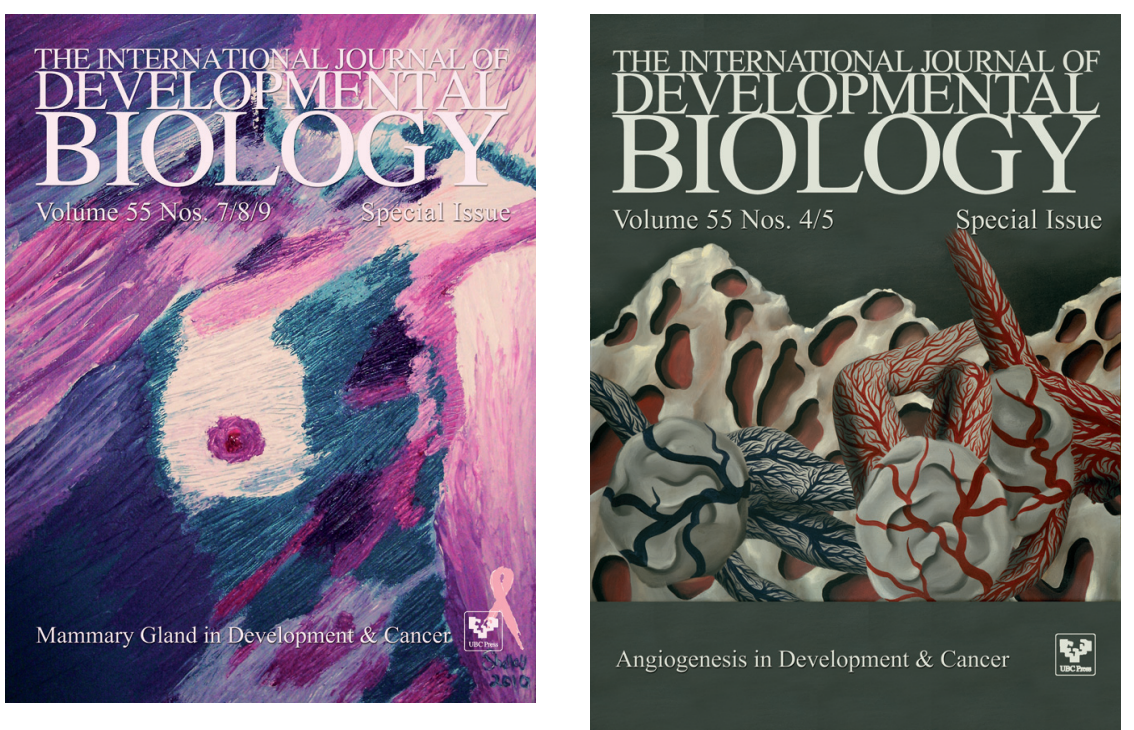